\title{
Success Results of High Performance and Potential System (HiPPS) Administration of Thai Government Departments
}

\author{
Ungsinun Intarakamhang \\ Behavioral Science Research Institute (BSRI), Srinakharinwirot University \\ 114 Sukhumvit 23 Rd., Bangkok, 10110, Thailand \\ E-mail: ungsinun@swu.ac.th \\ Wirin Kittipichai \\ Faculty of Public Health, Mahidol University \\ 420/1 Ratchawithi Rd., Bangkok, 10400, Thailand \\ E-mail: phwkt@mahidol.ac.th \\ Chutima Hanpachern \\ Senior Executive Service Center, Office of the Civil Service Commission \\ 47/101 Tiwanon Rd., Muang District, Nonthaburi, 11000, Thailand \\ E-mail: chutimah@ocsc.go.th \\ Piyasurang Kuljittiprasit \\ Senior Executive Service Center, Office of the Civil Service Commission \\ 47/101 Tiwanon Rd., Muang District, Nonthaburi, 11000, Thailand \\ E-mail: piyasurang@ocsc.go.th
}

Received: November 7, 2010 Accepted: December 7, $2010 \quad$ doi:10.5539/ass.v7n5p42

\begin{abstract}
The HiPPS was developed by the Office of the Civil Service Commission (OCSC). The aim of HiPPS was to prepare the Thai government officers with high performance and potential to develop and learn through the workplace as continual learning. The objectives of this research were 1) to evaluate the success in the HiPPS administration of the government departments, 2) to compare the opinions of the five sample groups about the success factors in the HiPPS administration, and 3) to investigate the problems in the use of HiPPS. The data were collected from five groups, 694 total samples from 42 government departments. The instruments were five rating-scale (1-5 level) questionnaires, in-depth interviews, and focus group interviews. Data was analyzed by ANOVA and the content analysis. The results indicated that overall, the average HiPPS administration of the government departments were fairly strength level in grade $\mathrm{B}(\overline{\mathrm{X}}=3.37)$. In the comparison among the opinions of the five sample groups about the success factors: Context, Input, Process, Product, Outcome, and Impact, there were also statistically significant differences at $.01\left(\mathrm{~F}=19.536^{* *}, 13.010^{* *}, 22.143^{* *}, 6.493 * *, 28.010 * *\right.$, and $6.211 * *$ respectively). Finally, the most found problems in HiPPS administration were as follows: lacking of cooperation from executives, existence of patronage system, lacking of definite HiPPS responsible unit, frequent change in HiPPS committee, incompetency of human resource management, negative attitude of increasing workload of the officers responsible for HiPPS.
\end{abstract}

Keywords: High performance, High potential, CIPP model, Talent management, Government officer 


\section{Introduction}

The Office of the Civil Service Commission (OCSC) serves as the secretariat of the Civil Service Commission and is the central agency in managing human resource and protecting merit system practices of the civil service. Furthermore, it evaluates and advances work quality, environment, and quality of life for government officers. This is to enable government officers to achieve their professional performance based on the principle of merit, good governance aiming at the benefit of the people and sustainable development of the nation (OCSC, 2005). The High Performance and Potential System (HiPPS) was developed by the OCSC applied of knowledge from talent management (Jeffrey, 2004) and it was used in 65 government departments for five years. In present, the 323 HiPPS officers pass training formally. The main objective of HiPPS was to prepare the government officers with high work performance and potential for development and experience learning through the workplace learning strategies: job rotation, coaching, mentoring, job delegation, in-house training, center training, secondment, shadowing, joint training, short-term attachments, and discussion group (Ashton \& Sung, 2002; Edwards \& other, 2004). Therefore, the government officers under HiPPS would progress in their career paths or become executives or experts, within a proper period of time which faster the government officers under regular human resource management system as the following in Figure 1.

\section{Objectives of the research}

The main purpose of this study was to evaluate the overall results and the potential in administrating the HiPPS system of 42 government departments in which the HiPPS officers class 1-3 are working. The sub-objectives of the study were as follows: 1) to establish a criterion and evaluation approaches for both the overall results and the potential of the attended government departments in HiPPS administration; 2) to evaluate the success in the HiPPS administration of the government departments upon their potentials; and 3) to investigate the problems and difficulties found in the use of HiPPS, and offer the OCSC the recommendation for improving and developing HiPPS.

\section{Method}

\subsection{Research design}

This research was based on evaluation research. In the evaluation, the CIPP Evaluation Model and Associated Relationships with Program of Stufflebeam \& Shinkfield (2007) and the Logic Model of Pankratz (2008) were employed to determine the success factors divided into 6 dimensions: Context, Input, Process, Product, Outcome, and Impact. The data collection method was operated by using the 360 Degree Feedback (Bartol \& others, 1998). The conceptual framework guiding this evaluation research is shown in Figure 2.

\subsection{Sample}

The sample group consisted of five groups of samples, 694 total persons from 42 government departments, which are as follows: 1) the group of executives of the government departments, 45 persons; 2) the group of officers in personnel division, 49 persons; 3) the group of supervisors coaching HiPPS officers, 93 persons; 4) the group of HiPPS government departments, 122 persons; and 5) the group of general officers comprising at least five persons from each government departments, 385 persons.

\subsection{Research Instruments}

The instruments used for data collection are the following: 1) five-rating-scale questionnaires (1-5 level) with 74 questions for the supervisors (Cronbach's alpha coefficient $=.815-.956$ ), 83 questions for the HiPPS officers (Cronbach's alpha coefficient $=.892-.953$ ), and 84 questions for the general officers (Cronbach's alpha coefficient $=.911-.967), 2$ ) structured interview with 34 questions for the officers in personnel division, and 3) semi-structured interview with 34 questions for executives.

\subsection{Research Procedures}

3.4.1 The evaluation framework was developed based on CIPP model and Logic model. The instruments were developed as self-assessment to quantify potential and performance in HiPPS administration in self- department.

3.4.2 The contents of total questionnaires were constructed from studying related theories and researches with strategy of new public management (OCSC, 2005), human resource management (Clark, 1992; Mondy \& Noe, 1996; Mondy, Noe \& Premeaux, 1999), HiPPS (OCSC, 2005), workplace learning (Boud \& Garrick, 1999; Ashton \& Sung, 2002; Dulworth \& Bordonaro, 2005), and talent management (Jeffrey, 2004). The reliability of the total instruments was $.815-.967$. The corrected Item- total correlation was .299-.869. 
3.4.3 The data were collected from five sample groups, by self-assessment for the supervisor, the HiPPS officers, and the general officer groups, individual in-depth interviews for the officer groups in personnel division, and focus group interviews for the executive groups in April - July 2010.

\subsection{Statistical Analysis}

The SPSS for windows was used in the descriptive statistical an analysis of the total data. The comparison among opinions of five sample groups was analyzed by One-way ANOVA. The qualitative data was analyzed by the content analysis. In evaluating the success in HiPPS administration of the government departments by the total scores obtained from the quantitative data. The government departments were ranged into eight levels upon their potentials. If the score shows between 1.01-1.50, the potential is under group grade $\mathrm{D}$, very weakness meaning the HiPPS administration of that government department needs urgent improvement, $(1.51-2.00=$ grade $\left.\mathrm{D}^{+}, 2.01-2.50=\mathrm{C}, 2.51-3.00=\mathrm{C}^{+}, 3.01-3.50=\mathrm{B}, 3.51-4.00=\mathrm{B}^{+}, 4.01-4.50=\mathrm{A}\right)$, if the score shows between 4.51-5.00, the potential is under group grade $\mathrm{A}^{+}$, meaning the HiPPS administration of that government department is excellent.

\section{Results}

\subsection{The quantitative results}

4.1.1 Overall, most of the samples had the idea that the HiPPS administration of the government departments were fairly strength level (B) with the mean $(\bar{X})$ of 3.37. When each group of samples was examined, the group of HiPPS officers and of supervisors coaching HiPPS officers were both found that the HiPPS administration of the government departments were good strength level $\left(\mathrm{B}^{+}\right)$with the same highest mean of 3.53. The group of general officers evaluated the lower value of 3.37 which was considered fairly strength level (B). The group of executives evaluated the next lower value of 3.21 which was deemed fairly strength level (B). The group of officers in personnel division evaluated the lowest mean of 2.83 which was considered fairly weakness level $\left(\mathrm{C}^{+}\right)$.

4.1.2 Each government department, having evaluated the potential, it was found that all of 42 departments were between the fairly weakness level $\left(\mathrm{C}^{+}\right)$and the good strength level $\left(\mathrm{B}^{+}\right)$with the mean of $2.65-3.87$. The department with the highest value of $3.87\left(\mathrm{~B}^{+}\right)$was the Office of the Permanent Secretary, Ministry of Energy. The next lower department which was at the good strength level $\left(\mathrm{B}^{+}\right)$comprised the Fiscal Policy Office, the Department of Mineral Fuels, and the Department of Lands with the mean of 3.85, 3.82, and 3.82 respectively. The lowest department was the Energy Policy and Planning Office with the mean of 2.65 ranked at the fairly weakness level $\left(\mathrm{C}^{+}\right)$. The second lowest departments were the Department of Fisheries, the Department of Land Transport, and the Department of the Comptroller General's with the mean of 2.81, 2.85, and 2.97 respectively ranked at the fairly weakness level $\left(\mathrm{C}^{+}\right)$

4.1.3 In the comparison among the opinions of the five sample groups, there was statistically significant difference at $.01\left(\mathrm{~F}=17.682^{* *}\right)$ for the total group' perspectives about the success factors: Context, Input, Process, Product, Outcome, and Impact. Having considered the perspectives in each factors, there were also statistically significant differences at $.01\left(\mathrm{~F}=19.536^{* *}, 13.010^{* *}, 22.143^{* *}, 6.493^{* *}, 28.010^{* *}\right.$, and $\left.6.211^{* *}\right)$. In the pair comparison analysis by Scheffe's method for the consideration of the difference and the agreement of the perspectives towards HiPPS administration between any two groups of samples, it was found that the group of HiPPS officers and of supervisors coaching HiPPS officers had the same perspectives both in each and overall success factors as the following in Table 1-2.

4.1.4 The potential evaluation regarding the six success factors of the 42 government offices was summarized as the following in Figure 3.

\subsection{The qualitative results}

4.2.1 Data obtained from focus group interviews and in-depth interviews with the executives, the results were as follows. For the Context aspect, it was found that the government departments were in need of HiPPS in order to continually develop the HiPPS officers and to persuade them to stay in the bureaucratic system. For the Input aspect, there was a preparation only to some extent. That is, human resource management was not prepared to specifically support the use of HiPPS; in contrast, it was prepared for the overall image of an department. For the Process aspect, it was found that the departments placed importance on HiPPS as can be seen from the participation of executives in the HiPPS committee, such as the chairman of the HiPPS selection committee. Also, there were a mission assignment to the department's the personnel development unit and a follow-up on the progress of HiPPS administration. For the Product aspect, it was found that HiPPS was capable of substantially drawing the potential from the high performance officers, of attracting the HiPPS officers to stay in 
the bureaucratic system for some time, and of preparing the HiPPS officers to be the department's efficient executives in the future. For the Outcome aspect, the HiPPS officers were well accepted among colleagues and supervisors as an officer who had high work potential, especially as the one who obtained more outstanding change leading skills than other general officers. For the Impact aspect, it was found that HiPPS was still incapable of creating impact to the departments as much as expected, because there was a small number of HiPPS officers working in the department. With this reason, change and innovations were difficult to be created within a short period of time.

4.2.2 Problems and obstruction in HiPPS administration most found were as follows: lacking of cooperation from executives, existence of patronage system, lacking of definite HiPPS responsible unit, frequent change in HiPPS committee, incompetency of human resource management, negative attitude of increasing workload of the officers responsible for HiPPS, inattention of the human resource department, failure of accomplishment in the experience accumulation framework (EAF), lacking of job rotation, short duration of work learning period, a great deal of specific work, a small number of HiPPS officers, lacking of goals in performing upon HiPPS, lacking of coaching officers, lacking of officers applying for HiPPS as unqualified upon the selection criteria, lacking of cooperation from general officers as lacking understanding in HiPPS, lacking of work morale of the officers, inefficiency of communication within the department, and unutilization of knowledge gained from training.

4.2.3 The factors found to support the efficiency of HiPPS administration were acceptance of both executives and officers, positive attitudes towards HiPPS, emphasis on importance of HiPPS, supports for HiPPS administration, comprehension and teamwork of human resource management officers, preparedness in budget and information technology, being a large department, organizational cultures that value learning and hard work, being a department filled with modern knowledge, challenging work, efficient human resource development system, explicit career path, explicit and continuous HiPPS officers development plan, willingness of a coach in passing on new knowledge, job rotation, teamwork building, being uncommitted to only one individual, ability of HiPPS officers to build their own inner strength, complying with a clear EAF, goal setting and agreement making between HiPPS officers and coaches in order to undergo the self-development process together.

\subsection{Recommendation for the OCSC}

4.3.1 From the evaluation of the overall results and the potential in HiPPS administration, there should be an exchange of experience and knowledge in pairs between the government departments whose evaluation results were at the fairly strength level (B) and those whose results were at the good strength level $\left(\mathrm{B}^{+}\right)$.

4.3.2 The group of officers in personnel division rated the HiPPS administration as fairly weakness level $\left(\mathrm{C}^{+}\right)$ which was the lowest compared to the other groups of respondents. This means that the officers responsible for HiPPS still had quite negative attitudes. Moreover, in the qualitative research, some respondents had the idea that HiPPS was difficult to manage and that it caused more workload to the personnel affairs department. Therefore, the Office of the Civil Service Commission (OCSC) should hold the activities that boost incentives, positive attitudes, and self-esteem.

4.3.3 The HiPPS officers from the departments with adequate performance $\left(\mathrm{C}^{+}\right)$should participate in group activities attended by several departments in order that knowledge and innovations can be reciprocally transferred. Alternatively, producing works for the organization should be one of the individual key performance indicators for the HiPPS officers.

4.3.4 The current number of HiPPS officers are not sufficient to cause change in the bureaucratic system; therefore, the criterion used in selecting officers eligible for HiPPS should be more flexible. That means there should be both central office and department criteria. The department should focus on an officer's work results and self-development. For example, the department should appoint weight to each success factor of the criterion by considering the department's necessity, vision, and mission, then use the total of the weighted scores in choosing the most eligible officers. As such, the department will have more opportunity to participate in the selected process.

4.3.5 The departments under HiPPS should generate more works and publicize them in a conference; thus, the transparency and the attempt to work for the society of the departments can be acknowledged in the social public. Accordingly, the state officers will be more acceptable and reliable to every section of society. Moreover, conducting public relations will results in gaining more supports from people and other related networks. 


\section{Discussion}

In the comparison of the opinion among the five sample groups. It was found that the group of HiPPS officers and of supervisors coaching HiPPS officers had the same perspectives both in each and overall success factors which were good strength level $\left(\mathrm{B}^{+}\right)$with the same highest mean of 3.53. In addition, it was found that the group of HiPPS officers and of supervisors coaching HiPPS officers had the same perspectives both in each and overall success factors: Context, Input, Process, Product, Outcome, and Impact. These findings also conform to study of the OSCS (2005) summarized that all of the group of HiPPS officers and of supervisors coaching HiPPS officers were the direct academic officers towards the experts, thus these groups would have more self-learning behavior and inspiration in good working. But, government officers in personnel division were academic supporting, thus they would be less alert. The detail of core competency found that the academic officers had to be higher performance than the academic supporting officers. In fact, the academic officers would make decision for complicated problem solving better by positive thinking. Therefore, HiPPS administration in their opinions was challenging job, complicated and not overloaded work, but built the strength of government offices. Thus, the opinion score of HiPPS officers and of supervisors coaching HiPPS officers were higher than of government officers in personnel division. In addition, the support factors related to strongly efficient HiPPS administration of the government departments. It was found that main factors were social support of the executives and general officers, positive attitudes, HiPPS officers acceptation, good teamwork of human resource officers, being a large department, learning organizational cultures, complicated challenging and complicated job, efficient human resource development system, explicit career paths, explicit and continuous HiPPS officer development plan, willingness of a coach in passing on new knowledge, job rotation, teamwork environment, being uncommitted to only one individual, ability of HiPPS officers to build their own inner strength, complying with a clear EAF. These factors would improve Thai bureaucratic system. This finding also corresponds with the concept of talent management in several countries to prepare the officers with high performance and potential for development and learning through the various action learning experience. (Schweyer, 2004; McGoldrick et al, 2005; Edwards, 2008; Malaysia Productivity Corporation, 2009; The Public Sector People Managers' Conference, 2010).

\section{Conclusion}

The purpose of HiPPS is to attract the talent officers, talent development and talent pool contribution in bureaucratic system. This findings, the most government departments had managed the HiPPS fairly strength level (grade B) which should achieve the goal of HiPPS by empowering of the OCSC continually. There should be the sharing of experience and knowledge by the learning conference among the executives, the supervisors, the officers in personnel division, the HiPPS officers, and general officers of the total government departments. The OCSC should hold the activities continually that boost incentives, positive attitudes, and self-esteem of very groups. In short term, the HiPPS officers can built the new product, innovation, creative of HiPPS officers increasing and continual. Finally, the general officers and executives will have confidence and positive attitude in HiPPS officers.

\section{Acknowledgements}

This study was part of HiPPS administration development financially supported by the OCSC, Prime Minister's Office in Thailand.

\section{References}

Aston, N. D., \& Sung, Johnny. (2002). Supporting workplace learning for high performance working. Geneva: International labor office.

Barry, C., \& Brian, K. (2001). Appraisal and learning in a government agency. The Learning Organization, 8(1), $21-35$.

Boud, D., \& Garrick, J. (1999). Understanding learning at work. NY: Routledge.

Clark, R. (1992). Human resources management: Framework and practice. Sydney: McGraw-Hill.

Cliffore, J. \& Thorpe, Sara. (2007). Workplace learning \& development: delivering competitive advantage for your organization. London: Kogan Page Limited.

Dulworth, M. \& Bordonaro, F. (2005). Corporate Learning: Proven and Practical Guidelines for Building a Sustainable Learning Strategy. San Francisco, CA: Pfeiffer.

Edwards, B. (2008). A customized approach to talent management at the University of Pennsylvania, Talent management strategies for attracting and retaining at the best and the brightest. CUPA-HR Journal, 59(1), 2-7.

Edwards \& et al. (2004). Rhetoric and educational discourse: persuasive texts. London: Routledge Falmer. 
Hager, P. (2003). Understanding workplace learning: General perspectives in current issues and new agenda in workplace learning: Republished online: Lea brook, Australia.

Jeffrey, B. (2004). Talent management - Valuing human capital. [Online] Available: http://www.cedma-europe.org/newsletter\%20articles/Clomedia/Talent\%20Management\%20-\%20Valuing\%20H uman\%20Capital\%20(May\%2004).pdf (February 14, 2009)

Jeffrey, B. (2008). Inclusive talent management top tips for the civil service. [Online] Available: http://www.civilservice.gov.uk/Assets/Inclusive-Talent-Management-Tips_tcm6-35851.pdf (May 14, 2009)

Malaysia Productivity Corporation. (2009). Talent management at government-linked companies (GLCs) transformation innovation partnership. [Online] Available: http://www.mpc.gov.my/mpc/images/file/Publication $\quad \% \quad$ 20House/Talent $\% 20$ Management $1 \%$ 20as\%20at \%20290110.pdf (March 14, 2009).

McGill, I. \& Beaty, L. (1995). Action Learning. $2^{\text {nd }}$ ed. London: Kokan Page.

McGoldrick \& Others. (2009). Talent management and the older workforce project team members. The Economic and Social Research Council. [Online] Available: http://www.esrc.ac.uk/ESRC InfoCentre/Images/Talent\%20management\%20and\%20the\%20older\%20workforce_tcm6-26383.pdf (February 14, 2009)

Mondy, R. W., \& Noe, R. M. (1996). Human Resource Management. Upper Saddle River, NJ: Prentice-Hall.

Mondy, R. W., Noe, R. M., \& Premeaux, S. R. (1999). Human Resource Management. $7^{\text {th }}$ ed. Upper saddle river, NJ: Asimon \& Schuster Company.

Pankratz, D. (2008). Program evaluation and community schools of the arts, purposes, concepts, and tools. [Online] Available: http://www.nationalguild.org/pdfs/ProgramEval.pdf (May 17, 2009).

Sambrook, S. (2006). Developing a model of factors influencing work-related learning: Findings from two research projects. In J. N. Streumer (Ed.), Work-related learning. Dordrecht: Springer.

Schermerhorn, J. R., Hunt, J. G. \& Osborn, R. N. (2000). Organizational Behavior. $7^{\text {th }}$ ed. NY: John Wiley \& Sons.

Schweyer, A. (2004). Talent management systems: best practices in technology solutions for recruitment, retention and workforce planning. Canada: John Wiley \& Son Ltd. Siemens. [Online] Available: http://www.siemens.co.uk (March 20, 2010).

Spence, J. (1998). Action learning for individual and organizational development. [Online] Available: http://ericacve.org/docs/pab00009.html (March 12, 2010).

Stufflebleam, D. L., \& Others. (1977). Education and decision making. $5^{\text {th }}$ ed. Illinois: F.E. Peacock.

Stufflebleam, D. L., \& Shinkfield, A. J. (2007). Evaluation theory, models, \& application. San Francisco: John Wiley \& Sons, Inc.

Sullivan, R. L. (1995). The competency-based approach to training. Baltimore, Maryland: JHPIEGO corporation.

Thad, G. (2000). Three steps to motivating employees. HR Magazine, 45(11), 155-158.

The Office of the Civil Service Commission (OCSC). (2005). Vision, mission, goals, and strategies. [Online] Available: http://www.ocsc.go.th/ocsccmsen/View1/view.jsp?contentID = CNT0000028 (March 2, 2009).

The Public Sector People Managers' Conference. (2010). Talent management. [Online] Available: http://publicsectorhrpodcast.co.uk (March, 21, 2010). 
Table 1. Comparison among the opinions of the five sample groups for the total groups' perspectives about the success factors: Context, Input, Process, Product, Outcome, and Impact by one way- ANOVA

\begin{tabular}{|c|c|c|c|c|c|}
\hline Source of variance & $\begin{array}{l}\text { Sum of } \\
\text { Square }\end{array}$ & Df & MS & $\mathbf{F}$ & $\mathbf{P}$ \\
\hline \multicolumn{6}{|l|}{ Overall factors } \\
\hline Between group & 21.299 & 4 & 5.325 & 17.682 & $.000 * *$ \\
\hline Within group & 207.182 & 688 & .301 & & \\
\hline Total & 228.480 & 692 & & & \\
\hline \multicolumn{6}{|l|}{ Context } \\
\hline Between group & 24.927 & 4 & 6.232 & 19.536 & $.000^{* *}$ \\
\hline Within group & 219.461 & 688 & .319 & & \\
\hline Total & 244.388 & 692 & & & \\
\hline \multicolumn{6}{|l|}{ Input } \\
\hline Between group & 21.307 & 4 & 5.327 & 13.010 & $.000^{* *}$ \\
\hline Within group & 280.459 & 685 & .409 & & \\
\hline Total & 301.766 & 689 & & & \\
\hline \multicolumn{6}{|l|}{ Process } \\
\hline Between group & 35.082 & 4 & 8.770 & 22.143 & $.000 * *$ \\
\hline Within group & 270.131 & 682 & .396 & & \\
\hline Total & 305.213 & 686 & & & \\
\hline \multicolumn{6}{|l|}{ Product } \\
\hline Between group & 12.440 & 4 & 3.110 & 6.493 & $.000 * *$ \\
\hline Within group & 327.619 & 684 & .479 & & \\
\hline Total & 340.060 & 688 & & & \\
\hline \multicolumn{6}{|l|}{ Outcome } \\
\hline Between group & 51.429 & 4 & 12.857 & 28.010 & $.000^{* *}$ \\
\hline Within group & 309.379 & 674 & .459 & & \\
\hline Total & 360.807 & 678 & & & \\
\hline \multicolumn{6}{|l|}{ Impact } \\
\hline Between group & 14.408 & 4 & 3.602 & 6.211 & $.000 * *$ \\
\hline Within group & 394.914 & 681 & .580 & & \\
\hline Total & 409.323 & 685 & & & \\
\hline
\end{tabular}

Note: Difference $* \mathrm{p}<0.05, \quad * * \mathrm{p}<0.01$

Table 2. Difference evaluation of the perspectives towards HiPPS administration in the pair comparison analysis by Scheffe's method

\begin{tabular}{|l|c|c|c|c|c|}
\hline \multicolumn{1}{|c|}{$\begin{array}{c}\text { Difference of the opinions } \\
\text { between group } \\
\text { (Total departments) }\end{array}$} & $\begin{array}{c}\text { HiPPS } \\
\text { officers } \\
\mathbf{N = 1 2 2}\end{array}$ & $\begin{array}{c}\text { General } \\
\text { officers } \\
\mathbf{N = 3 8 5}\end{array}$ & $\begin{array}{c}\text { Superviso } \\
\text { rs } \\
\mathbf{N = 9 3}\end{array}$ & $\begin{array}{c}\text { Officers in } \\
\text { personnel } \\
\text { division } \\
\mathbf{N = 4 9}\end{array}$ & $\begin{array}{c}\text { Executiv } \\
\text { es } \\
\mathbf{N = 4 5}\end{array}$ \\
\hline HiPPS officers & - & .16 & -.00 & $.70^{*}$ & $.32^{*}$ \\
General officers & & - & -.16 & $.54^{*}$ & .15 \\
Supervisors & & & - & $-70^{*}$ & $.32^{*}$ \\
Officers in personnel division & & & & - & $-.38^{*}$ \\
Executives & & & & & - \\
\hline
\end{tabular}

Note: Difference $* \mathrm{p}<0.05$ 


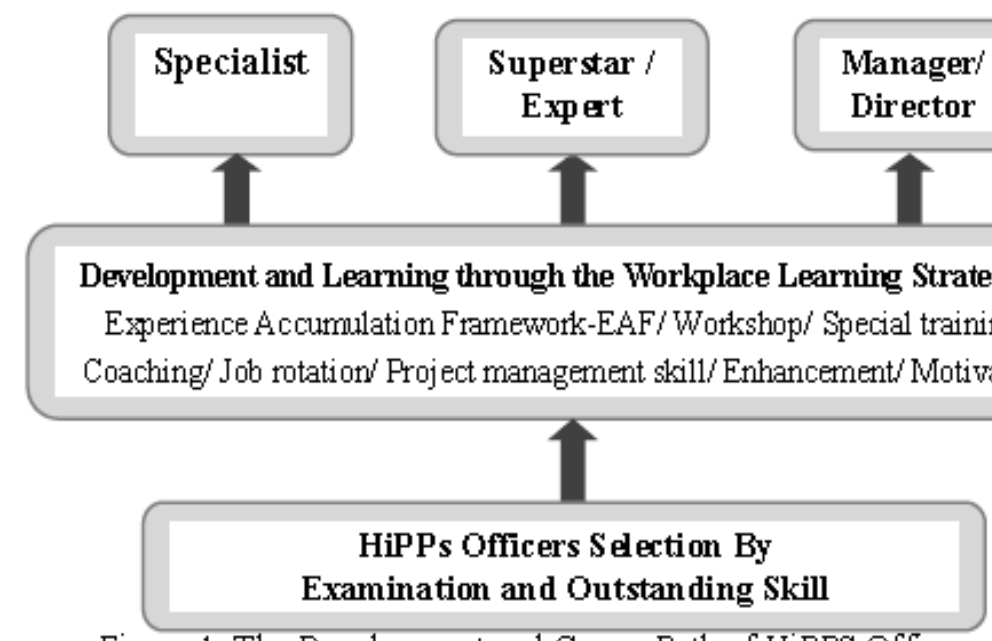

Figure 1. The Development and Career Path of HiPPS Officers

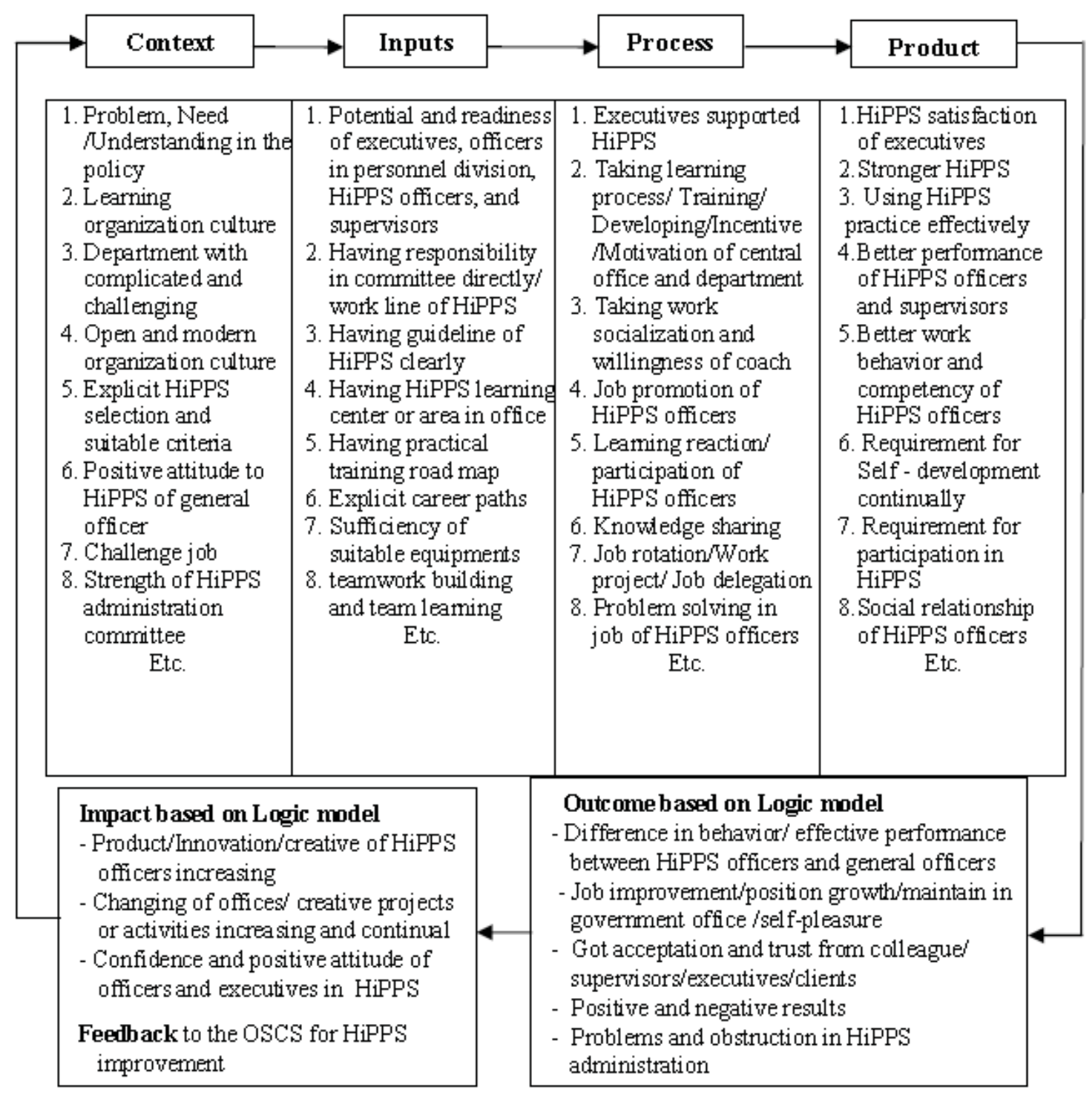

Figure 2. Conceptual framework of the evaluation in HiPPS administration of departments 


\begin{tabular}{|c|c|c|c|c|c|c|c|c|}
\hline$\underline{\text { Evaluation Results (Overall) }}$ & Evolution & G1 & G2 & G3 & G4 & G5 & Mean & $\begin{array}{l}\text { Gra } \\
\text { de }\end{array}$ \\
\hline & Context & 3.3 & 3.3 & 2.9 & 3.5 & 3.6 & 3.49 & B \\
\hline & & 3 & 4 & 1 & 7 & 0 & & \\
\hline \multirow{4}{*}{ cortext inpt proess podurt outcome inpact } & Input & 3.2 & 3.6 & 2.8 & 3.4 & 3.3 & 3.33 & B \\
\hline & & 7 & 2 & 3 & 1 & 1 & & \\
\hline & Process & 3.2 & 3.6 & 2.9 & 3.7 & 3.3 & 3.42 & B \\
\hline & & 3 & 8 & 3 & 5 & 4 & & \\
\hline$\underline{\text { Strengths }}$ & Product & 3.2 & 3.4 & 2.8 & 3.4 & 3.3 & 3.31 & B \\
\hline \multirow{3}{*}{$\begin{array}{l}\text { 1) The HiPPS got acceptation and was guideline } \\
\text { in the officer development continually and } \\
\text { efficiently. }\end{array}$} & & 5 & 3 & 9 & 4 & 0 & & \\
\hline & Outcome & 3.1 & 3.7 & 2.7 & 3.7 & 3.3 & 3.40 & B \\
\hline & & 6 & 7 & 4 & 2 & 2 & & \\
\hline \multirow{2}{*}{$\begin{array}{l}\text { 2) The department with complicated and } \\
\text { challenging missions helped the officers gain }\end{array}$} & Impact & 3.0 & 3.2 & 2.6 & 3.2 & 3.1 & 3.12 & B \\
\hline & & 2 & 7 & 5 & 2 & 2 & & \\
\hline $\begin{array}{l}\text { many experiences. } \\
\text { Weaknesses }\end{array}$ & Total & 3.2 & 3.5 & 2.8 & 3.5 & 3.3 & 3.37 & B \\
\hline \multirow{2}{*}{$\begin{array}{l}\text { 1) HiPPS officers couldn't rotate efficient. and } \\
\text { being fail to accomplish the EAF. }\end{array}$} & & 1 & 3 & 3 & 3 & 7 & & \\
\hline & Grade & B & $\mathbf{B}^{+}$ & $\mathbf{C}^{+}$ & B & $\mathbf{B}^{+}$ & B & B \\
\hline
\end{tabular}

2) There were inadequate officers in personnel division and potential of truly managing HiPPS within their department.

The group of HiPPS officers and of supervisors gave the highest evaluation value at 3.53. The next lowers were the group of general officers, executives, and officers in personnel division.

Remark $\mathbf{G 1}=$ Executives

G2 $=$ Supervisor

G3 $=$ Officers in personnel

division

$$
\begin{aligned}
& \mathbf{G 4}=\text { HiPPS officers } \\
& \mathbf{G 5}=\text { General officers }
\end{aligned}
$$

\section{Evaluation Results by Executives}

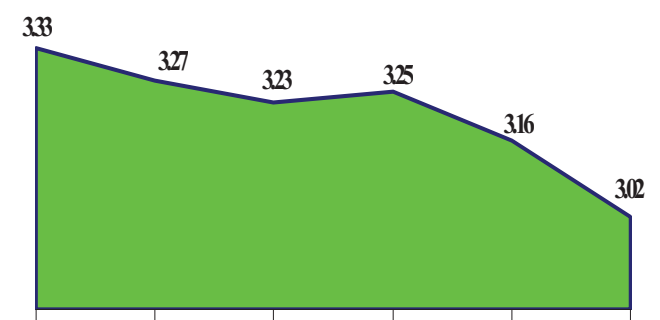

Context Input Process Produrt Otcome Inpact

\section{Strengths}

1) The department whose missions and work goals were challenging to HiPPS officers were good for gaining experiences.

2) The department needed to have an efficient personnel development system in order to maintain the high potential and outstanding officers in the department for a long time.

Weaknesses

1) Job rotation did not last long, so the HiPPS officers could not truly gain experiences and specific skills.

2) The HiPPS officers still could not create innovations for the department. 

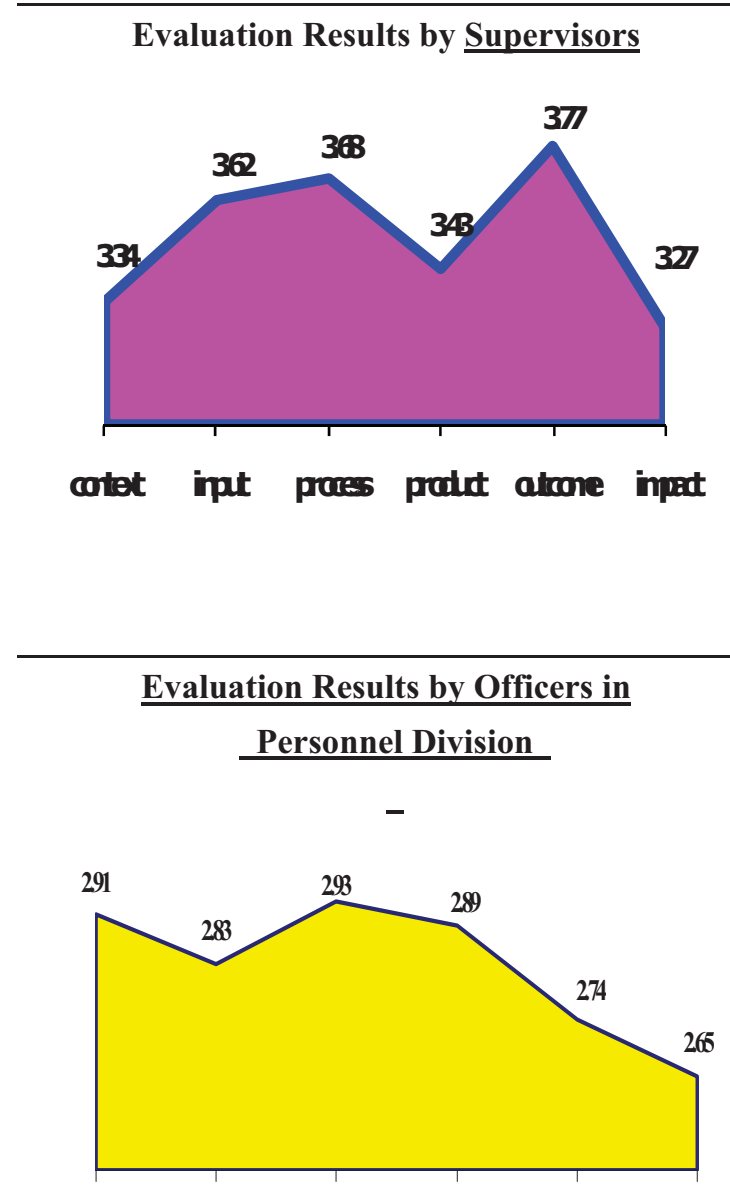

Context Input Process Product Ottome Impact

\section{Strengths}

1) The HiPPS officers were able to effectively perform the assigned tasks and finish them in a given time. They truly had high potentials.

2) The HiPPS officers were accepted by the executives and colleagues in that they had knowledge, ability, and human relations at work.

\section{Weaknesses}

1) The department lacked a management system and officers who were determined, considered, and seriously willing to manage HiPPS.

\section{$\underline{\text { Strengths }}$}

1) Learning about HiPPS from documents, internet, and attending the meetings held by OCSC helped understand more about the system.

2) Participation of the department's executives in the selection process of HiPPS resulted in transparency and justice.

\section{Weaknesses}

1) The department still could not be a good model in HiPPS administration for other departments.

2) The HiPPS officers still could not create innovations that can encourage concrete development.

Evaluation Results by HiPPS Officers

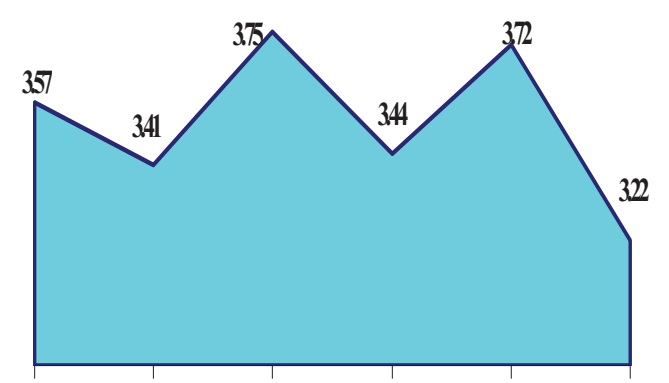

Contert Input Process Produrt Otrome Inpact

\section{Strengths}

1) Arranging training activities by the OCSC offered the HiPPS officers opportunities to participate. Also, documents about interesting and up-to-date knowledge were provided.

2) Accumulating knowledge by rotating jobs helped the HiPPS government officers perform self-development in that they encountered high challenging jobs and work closely with the department's executives.

\section{Weaknesses}

1) The department lacked efficiency in preparing for the use of HiPPS.

2) Jobs rotation for knowledge accumulation of the HiPPS officers lacked efficiency, and in some department it was difficult to perform.

3) The HiPPS officers lacked serious preparations before entering the system. 


\section{Evaluation Results by General Officers}

360

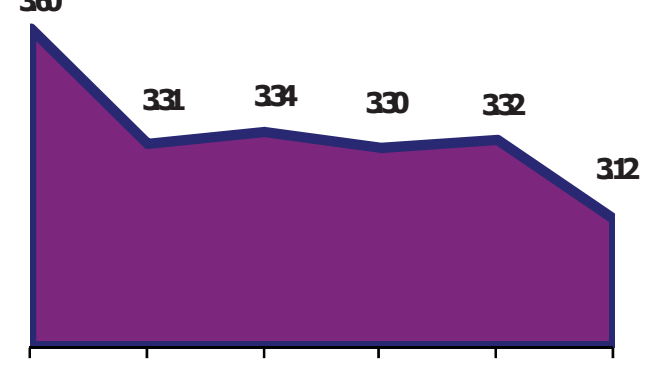

Cotet Int Proes Prodt atrone Inpat

1) The department whose missions were complicated and challenging to the HiPPS officers would be a good place for accumulating experience.

2) Hospitality found among officers in the department leaded to the efficiency in coaching the HiPPS officers. The HiPPS officers were encouraged to perform crucial tasks.

\section{Weaknesses}

1) Most of the general officers were still working based on results. Despite the fact that HiPPS had been employed in the department for some time, the number of change leaders did not increase.

2) HiPPS still could not truly stimulate the environment of learning and sharing knowledge within the department.

Figure 3. The potential evaluation regarding the six success factors of total 42 government offices was summarized 